- Bischof P. Observations on the isolation of pregnancy-associated plasma protein A. In: Klopper A, Chard T, eds. Placental proteins. Heidelberg: Springer-Verlag, 1979:105-18.

7 Thomson AM, Billewicz WZ, Hytten FE. The assessment of fetal growth. Fournal of Obstetrics and Gynaecology of the British Commonwealth $1968 ; 75: 903-12$

${ }^{8}$ Chard T. Normality and abnormality. In : Klopper A, ed. Plasma hormone assays in evaluation of fetal wellbeing. Edinburgh: Churchill Livingstone, 1976:1-19.
9 Klopper A, Smith R, Davidson I. The measurement of trophoblastic proteins as a test of placental function. In: Klopper A, Chard T, eds. Placental proteins. Heidelberg: Springer-Verlag, 1979:23-42.

${ }^{10}$ Lin TM, Halbert SP, Spellacy WN, Berne BH. Plasma concentrations of four pregnancy proteins in complications of pregnancy. Am 7 Obstet Gynecol 1977;128:808-10.

11 Klopper A. The new placental proteins. Placenta 1980;1:77-89.

(Accepted 17 December 1979)

\title{
Relation between extent of coronary artery disease and blood viscosity
}

\author{
G D O LOWE, MAUREEN M DRUMMOND, A R LORIMER, I HUTTON, C D FORBES, \\ C R M PRENTICE, J C BARBENEL
}

\section{Summary and conclusions}

Blood viscosity (shear rate $100 /$ s) and its major determinants (packed cell volume, plasma fibrinogen concentration, and plasma viscosity) were measured before coronary angiography in 50 men aged 30-55 and related to the extent of coronary artery disease. Twenty-six men had extensive disease (stenosis of two or three major coronary vessels), and 24 had either stenosis of one vessel or no stenosis. The 26 men with extensive disease had significantly higher mean blood viscosity than those with mild or no disease and 25 healthy controls $(p<0.001)$. The increased viscosity was due partly to a higher packed cell volume and partly to a higher fibrinogen concentration; plasma viscosity was not significantly increased. These differences could not be explained by smoking history.

These results suggest an association between increased blood viscosity and extensive coronary artery disease in men, which merits further investigation.

\section{Introduction}

Increased blood viscosity has been described in patients with clinical manifestations of occlusive arterial disease (previous myocardial infarction, angina, claudication) compared with control subjects. ${ }^{1-3}$ The relation of viscosity to the extent of coronary artery occlusion-the most important determinant of mortality in ischaemic heart disease - is, however, not known. We therefore studied blood viscosity and its major determinants (packed cell volume, plasma fibrinogen concentration, and plasma viscosity) in relation to the extent of coronary occlusion in men undergoing coronary arteriography.

University Department of Medicine, Royal Infirmary, Glasgow G4 OSF

G D O LOWE, MRCP, lecturer

C D FORBES, MD, FRCP, senior lecturer

C R M PRENTICE, MD, FRCP, reader

Bioengineering Unit, University of Strathclyde, Glasgow

MAUREEN M DRUMMOND, biochemist

J C BARBENEL, PHD, senior lecturer

University Department of Medical Cardiology, Royal Infirmary, Glasgow G4 OSF

A R LORIMER, MD, FRCP, consultant

I HUTTON, MD, FRCP, senior lecturer

\section{Patients and methods}

We studied 75 men aged 30-55 years after they had been admitted to Glasgow Royal Infirmary. Fifty were studied before they underwent selective coronary arteriography for assessment of chest pain: we excluded those with a history of myocardial infarction in the previous three months, those receiving treatment with diuretics (which cause haemoconcentration) or clofibrate (which lowers fibrinogen concentration and viscosity ${ }^{5}$ ), and those with overt cardiac failure. The extent of angiographic coronary occlusion was graded according to the number of major vessels (right, left anterior descending, and left circumflex coronary arteries) in which the lumen was occluded by $50 \%$ or more: patients were thus classified as having no disease or disease of one, two, or three vessels. Twenty-five men admitted for elective minor surgery served as controls: none had clinical evidence of vascular disease and in all a resting electrocardiogram was normal. Cigarette smokers were defined as those who had regularly smoked cigarettes within the previous three months.

Venous blood samples were taken from resting subjects between $11 \mathrm{am}$ and $1 \mathrm{pm}$ and anticoagulated with EDTA $(1 \mathrm{mg} / \mathrm{ml})$ for measurement of blood viscosity at $37^{\circ} \mathrm{C}$ (rhombospheroid viscometer, ${ }^{6}$ shear rate 100/s); packed cell volume (Hawksley microhaematocrit, $13000 \mathrm{~g}$ for five minutes); and plasma viscosity at $37^{\circ} \mathrm{C}$ (BS M3 capillary viscometer). Fibrinogen was determined by a thrombin-time method $^{7}$ in citrated plasma. The coefficient of variation for all these variables as measured by us is under $2 \%$. Differences in mean values were analysed by Student's $t$ test, and correlations by covariance analysis.

\section{Results}

Twenty-six men had extensive coronary occlusion: 16 had stenosis of two and 10 stenosis of three vessels. This group was compared with the 24 men who had relatively normal coronary arteries (eight with no stenosis and 16 with stenosis of a single vessel) and the 25 control subjects who had no clinical vascular disease. Table I shows that the three groups were comparable with regard to age and prevalence of smoking; history of smoking, weekly consumption of tobacco, and prevalence of inhaling were also comparable. The two groups of patients undergoing arteriography did not differ significantly in current use of beta-adrenergic blocking drugs or history of myocardial infarction.

TABLE I-Clinical data on patients studied

\begin{tabular}{|c|c|c|c|}
\hline & \multirow{2}{*}{ Controls } & \multicolumn{2}{|c|}{ Extent of stenosis } \\
\hline & & $\begin{array}{l}\text { None, or one } \\
\text { vessel }\end{array}$ & $\begin{array}{l}\text { Two or three } \\
\text { vessels }\end{array}$ \\
\hline 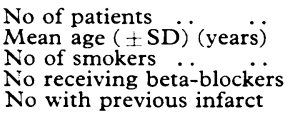 & $46 \cdot 1+5 \cdot 9$ & $\begin{array}{c}24 \\
45 \cdot 6 \pm 5 \cdot 5 \\
14 \\
14 \\
12\end{array}$ & $\begin{array}{l}26 \\
48 \cdot 2 \pm 5 \cdot 3 \\
16 \\
19 \\
16\end{array}$ \\
\hline
\end{tabular}


Mean blood viscosity was significantly higher $(p<0.001)$ in men with stenosis of two or three vessels compared with both the angiographic controls (no stenosis or stenosis of one vessel) and the asymptomatic controls (table II; figure). This increase in viscosity was associated with a higher mean packed cell volume $(p<0.005)$ and an increased mean fibrinogen concentration $(p<0.02)$. Mean plasma viscosity was also higher than that in the control groups, but the difference was not significant $(0 \cdot 1>p>0 \cdot 05)$. Covariance analysis of viscosity and its determinants, correcting for the effects of other variables, showed that blood viscosity correlated with packed cell volume $(r=0.7, p<0.001)$ and fibrinogen concentration $(r=0.4$, $\mathrm{p}<0.01$, and that plasma viscosity correlated with fibrinogen concentration $(r=0.4, p<0.01)$. After adjusting for variation in packed cell volume and fibrinogen concentration there was no correlation between blood and plasma viscosities. Blood viscosity and its determinants were not significantly different in men taking beta-blockers compared with men who were not, nor in men with a history of myocardial infarction compared with men with no such history.

TABLE II-Blood viscosity data (expressed as means $\pm S D$ )

\begin{tabular}{|c|c|c|c|}
\hline & \multirow{2}{*}{ Controls } & \multicolumn{2}{|c|}{ Extent of stenosis } \\
\hline & & $\begin{array}{c}\text { None, or one } \\
\text { vessel }\end{array}$ & $\begin{array}{c}\text { Two or three } \\
\text { vessels }\end{array}$ \\
\hline $\begin{array}{l}\text { Blood viscosity (mPa s) } \\
\text { Packed cell volume (\%) } \\
\text { Fibrinogen (g/l) } \\
\text { Plasma viscosity (mPa s) }\end{array}$ & $\begin{array}{l}6 \cdot 72 \pm 0 \cdot 37 \\
44 \cdot 7 \pm 2 \cdot 2 \\
2 \cdot 70 \pm 0 \cdot 55 \\
1 \cdot 38 \pm 0 \cdot 10\end{array}$ & $\begin{array}{l}6 \cdot 65 \pm 0.37 \\
44 \cdot 4 \pm 2 \cdot 4 \\
2 \cdot 73 \pm 0.66 \\
1 \cdot 39 \pm 0.08\end{array}$ & $\begin{array}{l}7 \cdot 24 \pm 0 \cdot 50 \\
47 \cdot 2 \pm 2 \cdot 9 \\
3 \cdot 19 \pm 0 \cdot 66 \\
1 \cdot 43 \pm 0 \cdot 10\end{array}$ \\
\hline
\end{tabular}

Conversion: SI to traditional units-Viscosity: $1 \mathrm{mPa} \mathrm{s}=1 \mathrm{cP}$



Blood viscosity and packed cell volume in patients studied. $O=$ Controls. $=$ Patients with no stenosis or stenosis of one vessel only. $\times=$ Patients with stenosis of two or three vessels.

Conversion: SI to traditional units-Blood viscosity: $1 \mathrm{mPa} \mathrm{s}=1 \mathrm{cP}$.

\section{Discussion}

These results suggest an association between increased blood viscosity and extensive coronary artery occlusion in men. While coronary artery disease progresses throughout life, ${ }^{8}$ it is people with extensive coronary stenosis who tend to die from ischaemic heart disease. ${ }^{4} 8$ Healthy middle-aged American men often have one stenosed vessel, ${ }^{8}$ and we found no difference in viscosity or its determinants when comparing men with arteriographic evidence of disease of one vessel and men with no clinical evidence of vascular disease. On the other hand, men with stenosis of two or three vessels before the age of 56-that is, those at risk of premature death-had increased blood viscosity. This appeared to be due to the combination of increased packed cell volume and increased fibrinogen concentrations, as found in patients with claudication ${ }^{2}$ and angina. ${ }^{3}$ Plasma viscosity tended to increase with the plasma fibrinogen concentration but was not significantly higher in the group with extensive stenosispossibly owing to differences in other plasma proteins. The association of packed cell volume and fibrinogen concentration with extensive arterial disease may explain why, in prospective studies, risk associations for vascular events include high concentrations of haemoglobin ${ }^{1011}$ and erythrocyte sedimentation rate $^{11}$ (which reflects plasma fibrinogen concentration).

The mechanisms by which packed cell volume and fibrinogen concentration are raised in men with arterial disease are not known. Cigarette smokers have a higher viscosity, packed cell volume, and fibrinogen concentration than non-smokers, ${ }^{12}$ but in this study the increased viscosity in men with extensive coronary disease could not be explained by differences in smoking history. Whatever the mechanism by which it arises, increased viscosity may play a part in the development of ischaemic heart disease. Fluid dynamic factors may be important in localising atherosclerotic lesions, ${ }^{13}$ and increased blood viscosity may alter some of these in directions favouring mural thrombosis or insudation of plasma components into the arterial wall. Relatively small increases in packed cell volume and viscosity are associated with relatively large decreases in blood flow in the $\operatorname{limbs}^{14}$ and brain,,$^{15}$ and decreased blood flow may precipitate ischaemia and thrombosis in stenosed arteries. ${ }^{9}$ The combination of vessel stenosis (which lowers shear rates and hence increases blood viscosity locally), increased packed cell volume, and increased plasma viscosity and aggregation of red cells owing to high fibrinogen concentrations may also produce pronounced adverse effects on blood flow in the microcirculation. ${ }^{16}$ The association of viscous blood and stenosed arteries may therefore have serious consequences, and studies of the effect of reducing blood viscosity in managing coronary artery disease merit consideration.

We thank Dr Monica Jordan of the Bioengineering Unit, University of Strathclyde, for performing the covariance analysis.

Requests for reprints should be sent to GDOL.

\section{References}

1 Mayer, GA. Blood viscosity in healthy subjects and patients with coronary artery disease. Can Med Ass $\mathcal{F} 1964$;91:951-4.

2 Dormandy, JA, Hoare E, Colley J, Arrowsmith DE, Dormandy TL. Clinical, haemodynamic, rheological, and biochemical findings in 126 patients with intermittent claudication. $\mathrm{Br}$ Med f 1973;iv:576-81.

${ }^{3}$ Nicolaides AN, Bowers R, Horbourne T, Kidner PH, Besterman EM Blood viscosity, red-cell flexibility, haematocrit, and plasma-fibrinogen in patients with angina. Lancet 1977,ii:943-5.

4 Griffith LSC, Achuff SC. Coronary arteriography and left ventriculography. In: Julian DG, ed, Angina Pectoris. Edinburgh: Churchill Livingstone, 1977:164-95.

5 Dormandy JA, Gutteridge JMC, Hoare E, Dormandy TL. Effect of clofibrate on blood viscosity in intermittent claudication. $\mathrm{Br} \mathrm{Med} \mathcal{f}$ 1974 ;iv :259-62.

6 Dintenfass L. A coaxial rhombo-spheroid viscometer: a further development of the cone-in-cone viscometer. Biorheology 1969;6:33-6.

7 Clauss A. Gerinnungsphysiologische Schnellmethode zur Bestimmung des Fibrinogens. Acta Haematol (Basel) 1957;17:237-46.

${ }^{8}$ McGill HC Jr, ed. The geographic pathology of atherosclerosis. Baltimore: Williams and Wilkins, 1968.

${ }^{9}$ Roberts WC, Ferrans VJ. The role of thrombosis in the etiology of atherosclerosis (a positive one) and in precipitating fatal ischaemic heart disease (a negative one). Semin Thromb Hemostas 1976;2:123-35.

${ }^{10}$ Kannel WB, Gordon T, Wolf PA, McNamara PM. Haemoglobin and the risk of cerebral infarction : the Framingham study. Stroke $1972: 3 ; 409-20$.

11 Bottiger LE, Carlson LA. The Stockholm prospective study 2 . New events of coronary heart disease in men in relation to findings at initial examination, 9-year follow up. In: Waldenstrom J, Larsson T, Ljungstedt $\mathrm{N}$, eds. Early phases of coronary heart disease: the possibility of prediction. Stockholm: Nordiska Bokhandelns Forlag, 1973: 158-81.

12 Dintenfass L. Elevation of blood viscosity, aggregation of red cells, haematocrit values and fibrinogen levels in cigarette smokers. Med $\mathcal{f}$ Aust $1975 ; 1: 617-20$.

13 Bergel DH, Nerem RH, Schwartz CJ. Fluid dynamic aspects of arterial disease. Atherosclerosis $1976 ; 23: 253-61$.

14 Dormandy JA. Influence of blood viscosity on blood flow and the effect of low molecular weight dextran. $\mathrm{Br}$ Med $\mathcal{F} 1971$;iv:716-9.

15 Thomas DJ, du Boulay GH, Marshall J, et al. Effect of haematocrit on cerebral blood-flow in man. Lancet 1977;ii:941-3.

16 Schmid-Schönbein H. Microrheology of erythrocytes, blood viscosity, and the distribution of blood flow in the microcirculation. In: Guyton AC, Cowley AW, eds. International review of physiology, cardiovascular physiology II. Vol 9. Baltimore: University Park Press, 1976:1-62.

(Accepted 19 December 1979) 